\title{
Bevoegdheidsafbakening van de AROB-rechter; kunstig of gekunsteld?
}

Citation for published version (APA):

Tak, A. Q. C. (1984). Bevoegdheidsafbakening van de AROB-rechter; kunstig of gekunsteld? Kluwer. https://doi.org/10.26481/spe.19840120at

Document status and date:

Published: 20/01/1984

DOI:

10.26481/spe.19840120at

Document Version:

Publisher's PDF, also known as Version of record

\section{Please check the document version of this publication:}

- A submitted manuscript is the version of the article upon submission and before peer-review. There can be important differences between the submitted version and the official published version of record.

People interested in the research are advised to contact the author for the final version of the publication, or visit the DOI to the publisher's website.

- The final author version and the galley proof are versions of the publication after peer review.

- The final published version features the final layout of the paper including the volume, issue and page numbers.

Link to publication

\footnotetext{
General rights rights.

- You may freely distribute the URL identifying the publication in the public portal. please follow below link for the End User Agreement:

www.umlib.nl/taverne-license

Take down policy

If you believe that this document breaches copyright please contact us at:

repository@maastrichtuniversity.nl

providing details and we will investigate your claim.
}

Copyright and moral rights for the publications made accessible in the public portal are retained by the authors and/or other copyright owners and it is a condition of accessing publications that users recognise and abide by the legal requirements associated with these

- Users may download and print one copy of any publication from the public portal for the purpose of private study or research.

- You may not further distribute the material or use it for any profit-making activity or commercial gain

If the publication is distributed under the terms of Article $25 \mathrm{fa}$ of the Dutch Copyright Act, indicated by the "Taverne" license above, 


\section{BEVOEGDHEIDSAFBAKENING VAN DE AROB-RECHTER; KUNSTIG OF GEKUNSTELD?}

\section{REDE}

uitgesproken bij de aanvaarding van het ambt van gewoon hoogleraar in het recht, in het bijzonder in het staatsrecht en het administratief recht aan de Rijksuniversiteit Limburg te Maastricht op vrijdag 20 januari 1984

door

MR.A.Q.C.TAK 
ISBN 9026814542

(1984 Mr. A.Q.C. Tak. Meerssen

Behoudtens uitzondering door de Wet gesteld mag zonder schriftelijke toestemming van de rechthebbende(n) op het auteursrecht, c.q. de utitgefster van deze uitgave, door de rechthebbende(n) gemachtigd namens hem (hen) op te treden, niets uit deze uitgave worden werveelvoudigd en/of openbata gemakt door middel van druk, fotokopie, microfilm of anderszins thetgeen ook van toepassing is op de gehele of gedeelrelijke bewerking.

De kitgeefster is met uitsluiting van ieder ander gerechtigd de door derden verschuldigde vergoedingen van kopiè ren, bedoeld in artikel 17 lid 2. Auteurswet 1912 en in het K. B. wan 20 jun $1974(S t b .351)$ ex artikel 166 Auteurswe 1912, te innen en/of datartoe in en buiten rechte op te treden. 
De onbevangen lezer van uitspraken van de Afdeling rechtspraak zal zich vak verwonderd afvragen, waarom een bepaalde zaak niet in behandeling werd genomen, terwijl zulks wel gebeurde met andere, sterk gelijkende of bijna identieke zaken. Een greep uit de jurisprudentie van de Afdeling kan dit illustreren.

Een inwoner van Valkenburg vroeg aan $B$ en W om in aanmerking te worden gebracht voor een woning, die gebouwd zou worden in het kader vatn een nieuw bestemmingsplan, dan wel voor de aankoop van een perceel grond in dat plan. Het College van $B$ en $W$ weigerde. Betrokkene bofte, want hij werd door de Afdeling rechtspraak ontvangen in zijn beroep tegen dit weigeringsbesluit. ${ }^{I}$ In Leidschendam werd door de gemeente een loting georganiseerd tussen gegadigden voor premie-koopwoningen. Een gegadigde die buiten de prijzen viel, kreeg op zijn daartegen gericht $A R O B-b e r o e p$ in vereenvoudigde afdoening te verstaan, dat hij niet in dat beroep kon worden ontvangen. Volgens de Voorzitter hield het op grond van de loting genomen afwijzingsbesluit namelijk de weigering in om een rechtshandeling naar burgerlijk recht te verrichten. ${ }^{2}$ Nu was dat volgens de Afdeling ook wel het geval in de Valkenburgse. kwestie, maar daar was tevens sprake van een beschikking in de zin van artikel 2 Wet AROB, omdat aan de weigering on betrokkene op de lijst van gegadigden te plaatsen óok het rechtsgevolg was verbonden dat hij te zijner tijd niet in aanmerking zou komen voor een woonnuimtevergunning.

Een aantal zielzorgers in Limburg verwachtte nadeel in hun werk en in de uitoefening van thun levensroeping toen door de Burgemeester van Roermond vergunning werd verleend voor het houden van een demonstraticve optocht door de Nederlandse Vereniging tot integratie van homoseksualiteit $\mathrm{COC}$, afdeling Limburg. De demonstratic was gericht tegen controversicle uitspraken van de Bisschop van Roermond. Deze zielzorgers werden door de Voorzitter Afdeling rechtspraak in hun schorsingsverzoek ontvangen, zij het dat dit verzoek vervolgens door de Voorzitter werd afgewezen. ${ }^{3}$ Anders verging het deze zielzorgers evenwel in de behandeling ten gronde van hun beroep door de Afdeling rechtspraak zelf. Door de Afdeling werden zij in hun beroep niet-ontvankelijk verklaard, omdat zij noch in Roermond woonachtig waren noch daar werkzaam waren als privé-personen of als zielzorgers. ${ }^{*}$ Opmerking verdient, dat het schorsingsverzoek op 11 april 1979 was afgewezen, de demonstratieve optocht had plaatsgevonden op 14 april 1979 en de uitspraak van de Afdeling rechtspraak zelf pas werd gedaan op 8 januari 1981. Men kan zich afvragen hoe deze kwestie had moeten worden opgelost als de Voorzitter nu eens het schorsingsverzoek had toegewezen, doch dit terzijde. 
Dat aan het woonachtig zijn in een gemeente ook weer geen overdreven gewicht moet worden toegekend, moge blijken uit de uitspraak inzake de vergunningverlening door $B$ en W van Woudrichem voor de bouw van een nieuw raadhuis. Een inwoner wan Woudrichem stelde tegen die vergunningverlening AROB-beroep un. Van de Afdeling rechtspraak kreeg hij echter te horen, dat hij niet ontvankelijk was in dat beroep. ${ }^{5}$

Het College var $B$ en $W$ van Rotterdam weigerde om aan de Stichting Mayibuye te Leiden een vergunning te geven voor het houden van collectes ten bate van de Zuidafrikaanse vakbond SACTU (South African Congress of Trade Unions). Het Nederlands Juristen Comité voor de Mensenrechten stelde AROB-beroep in tegen deze weigering. Het comité werd gezien zijn doelstelling ontwankelijk geacht in dit beroep. ${ }^{6}$ Toen echter in de bekende kwestie van de Paralympics de Minister besliste om de toegezegde steun aan de Olympische Spelen voor Gehandicapten afhankelijk te stellen van het niet-deelnemen van een Zuidafrikaans team, werd een groot aantal natuurlijke personen zowel als stichtingen niet ontvangen in hun tegen die beslissing ingestelde AROB-beroep. Wel daarentegen werd in zijn beroep tegen dit besluit ontwangen de Zuidafrikaanse sportbond voor gehandicapten. ${ }^{7}$ In dit verband van doelstellingen van rechtspersonen kunnen ook enkele uitspraken worden gesignaleerd, waarbij werd beslist dat het feir, dat een politieke partij het behartigen van het algemeen belang (zoals zij dat ziet) in haar algemene doelstelling heeft opgenomen, niet met zich meebrengt, dat zo'n partij AROB-beroep zou kunnen instellen tegen beschikkingen die zich met die doelstelling niet verdragen, doch die de partij zelf als zodanig niet raken. ${ }^{8}$

Ook de kwestie van het "uitwegen" van particulier terrein naar openbare wegen geeft een merkwardig beeld aan ontvankelijkheidsuitspraken te zien. Ik ga hier nog maar stilzwijgend voorbij aan de verschillen in opvatting tussen Hoge Raad, Kroon en Afdeling rechtspraak ${ }^{9}$ en beperk me weer tot de laatste. Het College van B en W van Avereest deed aan een particulier op diens verzock een aanbod om tot een regeling te geraken inzake het verbreden wan een uitweg over gemeentegrond. Dit aanbod bleek niet vatbaar woor AROB-beroep, omdat voor dat geval een publiekrechtelijke regeling ontbrak en er 'dus' sprake was van een aanbod tot het aangaan wan een overeenkomst naar burgerlijk recht, aldus de Aldeling rechtspraak. ${ }^{10}$ Wel appellabel bij de AROBrechter is volgens gevestigde jurisprudentie het vorderen van een geldbedrag voor het ontsluiten van particulier bouwterrein, het 'uitwegen', ook al is dat vorderen gebaseerd op een zgn. gemeentelijke bijdrageregeling die uitdrukkelijk het etiket 'privatrechtelijk' voert. ${ }^{11}$ Als echter het bedrag is betaald en het gemeentebestuur weigert on dit terug te betalen, dan wordt men in een beroep tegen dat weigeringsbesluit door de Afdeling rechtspraak niet ontwangen. ${ }^{12}$ Dit lijkt merkwardig, omdat deze zelfde instantie in vaste jurisprudentie het eisen van zodanige betalingen onrechtmatig, $j a$, in strijd met de wet 
oordeelt. ${ }^{13}$ Weigeringen tot terugbetaling zijn echter volgens de Afdeling niet appellabel in AROB-beroep, ondat zij geacht moeten worden rechtshandelingen naar burgerlijk recht te betreffen. Maar dat is alweer anders, als tegen zo'n weigering een publiekrechtelijke rechtsgang is opengesteld. ${ }^{4}$

Als toetje nog enkele voorbeelden die zijn ontleend aan de wisselvallige AROB-jurisprudentie inzake aanwijzing van beschermde natuurgebieden. Besluiten, dat aanwijzing van een bepaald gebied als beschermd natuurmonument in overweging was, werden niet appellabel geacht in onder andere de kwesties van de 'Kop van Schouwen'15, de 'Korendijsche Slikken'16 (NB: vereenvoudigd afgedaan!) en de 'Kleiput in de Tiendgorzen". ${ }^{17}$ Wél appellabel werd dit soort besluiten geacht in onder andere de uitspraak inzake de Waddenzee.$^{18}$ In de kwestie van het 'Landgoed Kortenhoeff" werden de appellanten door de Voorzitter in de schorsingsprocedure wel in hun beroep ontvankelijk geacht ${ }^{19}$, doch niet door de Afdeling in de behandeling ten gronde ${ }^{20}$

Gezien deze voorbeelden moet in vele gevallen de rechtstoepassing door de Afdeling rechtspraak in geschillen met de overheid wel onbegrijpelijk zijn voor de burger. De uitslag van geschillen is in vele gevallen onvoorspelbaar. Slechts enkele specialisten menen nog lijnen te kunnen ontdekken in deze rechtstoepassing. ${ }^{21}$ Hoewel het probleem daarvóór ook reeds latent aanwezig was, is het vooral sinds de inwerkingtreding van de Wer AROB manifest geworden. Zulks werd veroorzaakt doordat de rechtsmacht van de AROB-rechter afhankelijk werd gesteld van een rechtsbegrip. Ik doel hiermee op de schijnbaar eenvoudige definitie van een voor AROB-beroep vatbaar overheidsbesluit, te weten het beschikkingsbegrip in de zin van de Wet AROB.

Het is de koppeling van de rechtsmacht van de $A R O B$-rechter aan dit beschikkingsbegrip, die mijns inziens voor een belangrijk deel debet is aan de ondoorzichtigheid van de rechtsmacht van de. Afdeling rechtspraak, en daarmee aan de onvoorspelbaarheid in vele gevallen van de wel of niet ontvankelijkheid in AROB-beroepen.

Om de oorzaken van de gesignaleerde wisselvalligheid in de jursprudentie op te sporen, lijkt eerst nader onderzoek geboden naar de vraag, walarom de competentie van deze belangrijkste der administratieve rechters aflankelijk werd gesteld van cen begrip, te weten het beschikkingsbegrip, zoals in principe omschreven in artikel 2 van de Wet AROB.

Twee historische lijnen zijn hierbij bepalend geweest. De meest in het oog springende was die van de gegroeide leemte in de rechtsbescherming, warin moest worden voorzien door algemene alanvullende administratieve rechtspraak. Deze lijn, die reeds bij de Wet BAB te vinden was, is reeds door anderen duidelijk beschreven ${ }^{22}$, zodat ik hier volsta met een enkele opmerking. Het karakter van de AROB-rechtspraak als algemeen en aamvullend het geen omschrijving toe wan de rechtsmacht aan de hand van wetten of rechtsgebie- 
den zoals ambtenarenzaken, sociale-zekerheidskwesties, belastingaangelegenheden of economische-ordeningsgeschillen. ${ }^{23}$ Veeleer was noodzakelijk een afbakening van de bevoegdheidsgrenzen met wooral wetgever, wolksvertegenwoordiging, administratief-beroepsorganen, andere adminstratieve rechters dan de Afdeling rechtspraak zelf, en met de burgerlijk rechter.

Hiertoe werd gebruik gemaakt van de verworvenheder uit de tweede historische lijn.

De gedachte aan een overheid, die staat boven het (althans gemene) recht, is nimmer geheel verdwenen. Ondanks het (in theorie) loslaten van die gedachte bij de overwinning van de leer van de rechtssoevereiniteit blijft het streven naar een bijzondere behandeling van de overheid in het recht duidelijk merkbaar. Gevolg daarvan (of middel daartoe?) was en is een bijzonder, eigen juridisch begrippenkader (beschikking, algemene beginselen van behoorlijk bestuur, bestuurswrijheid, beshitenvan algemene strekking, e.t.q.). De introductie van het beschikkingsbegrip door Van der Pot in $1932^{2.4}$ leek decennia lang de gouden wondst om de bijzondere positie van de overheid juridische identiteit te geven: haar doen en laten liet zich juridisch schijnbaar rubriceren in (vooral) wetgeving en beschikking. Daarnaast was het die overheid 'uiteraard' toegestaan om op gelijke voet als privaat persoon aan het gewone rechtsverkeer deel te nemen: kocht zij potloden voor haar ambtenaren, dan handelde zij niet als overheid "als zodanig"25, evenmin als wanneer zij rioolwaterlozingen op het IJsselmeer bestreed als eigenares van dat water. ${ }^{26}$ 'Uiteraard' kon ook zij 'puur feitelijk' handelend in de fout gaan en onrechtmatige daden plegen. Dat overigens in beide gevallen (zowel dus bij het stellen van rechtshandelingen 'naar burgerlijk recht' als bij het plegen van onrechtmatige daden) toch ook nog een bijzondere behandeling van de overheid werd verlangd, blijkt wel uit de ontwikkeling van de jurisprudentie inzake het niet-nakomen van verbintenissen uit contract ${ }^{27}$ en - vooral - inzake onrechtmatige overheidsdaden. ${ }^{28}$ Aarzelende pogingen om aan te tonen, dat het beeld ondeugdelijk, althans onvolledig was, dat er ook andere vormen van bestuurlijke besluiten en handelingen voorkwamen en dat er bijvoorbeeld ook bestuursbesluiten voorkwamen in de gedaante van een 'concrete norm', zoals Belinfante het typeerde ${ }^{29}$, werden afgestraft met het begripsmatige dogma: "de norm is per definitic abstract:, ${ }^{30}$

Illustraticf voor de begripsworming in het besturrsrecht - overigens al evenzeer een juridisch begrip met gekunstelde grenzen als het beschikkingsbegripis nog steeds het schema van bestuurshandelingen in het gezaghebbende Rapport ABAR ${ }^{31}$ : 


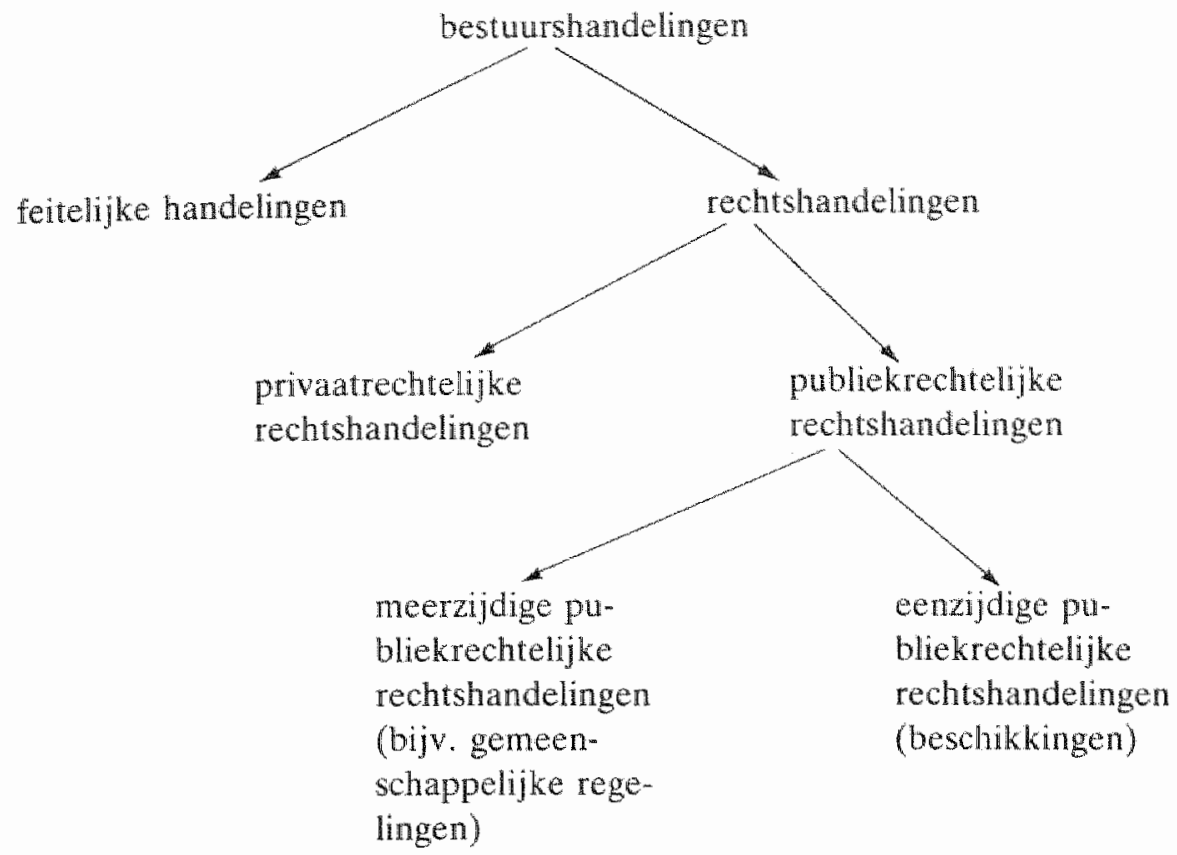

Veelzeggend voor de overheersende betekenis die aan het beschikkingsbegrip wordt toegekend is, dat het Rapport constateert, dat van de publiekrechtelijke rechtshandelingen de eenzijdige, welke als beschikking pleegt te worden aangeduid, verreweg de meest voorkomende is. ${ }^{32}$ Hoewel dit Rapport pretendeert te komen tot algemene bepalingen ('conclusies') van administratief recht, beperkt het zich ook nagenoeg geheel tot algemene bepalingen inzake 'beschikkingenrecht'. Opgemerkt wordt, dat '...ook de wet in materiële zin (...) uiteraard als eenzijdige publiekrechtelijke rechtshandeling te kwalificeren (is); zij blifft hier echter als zodanig buiten beschouwing omdat zij per definitionem niet tot de bestuurshandelingen kan worden gerekend?. ${ }^{33}$ (De defini* tie van 'bestuur' in het Rapport is overigens weer een negatieve, dus in wezen slechts probleemverschuivende: "alle werkzaamheid van de overheid welke niet als wetgeving of rechtspraak is aan te merken"). ${ }^{34}$ De reeds gememoreerde 'concrete norm' van Belinfante wordt wel weergegeven ${ }^{35}$, doch beschouwingen daarover blijven achterwege, laat staan het trekken van conclusies daaruit.

Vanuit deze tweede lin valt te verklaren, dat de algemene, aanvullende competentie wan de Afdeling rechtspraak afhankelijk werd gesteld van het in het bestuursrecht dominerende juridische begrip "beschikking", zoals dat werd neergelegd in (vooral) artikel 2 van de Wet AROB. De eenvoud van de omschrijving van dit begrip in artikel 2 is bedrieglijk. Impliciet vergt deze begrips- 
onschrijving in haar relatie tot de rechtsmacht tevens een definiering van verscheidene andere begrippen; begrippen als "administratief orgaan"36. "openbaar gezag" 37, "wetgevende macht'38, "rechterijke macht" ${ }^{39}$, "rechtspraak" 40 . 'feitelijk besluit' (tegenover 'besluit gericht op enig rechtsgevolg') ", "besluit van algemene strekking"42, "rechtshandeling naar burgerlijk recht" 43 " "administratiefrechtelijke voorziening"44, "financiële bijdrage"45, "belasting" 46 "belang'47, 'persoonlijk belang', "en het 'rechtstreeks getroffen zijn' in enig persoonlijk belang. ${ }^{45}$ De wetsgeschiedenis geeft weinig toelichting op deze begrippen die zo cruciaal zijn voor de rechtsmacht van de Afdeling rechtspraak. ${ }^{50}$ Werden ze dermate duidelijk geacht dat gedegen toelichting overbodig was? De overvloedige stroom van jurisprudentie naar aanleiding van deze begrippen lijkt eerder de conclusie te dragen dat sprake is van grote onduidelijkheid.

Men kan zich afvragen of het eigenlijk wel mogelijk is om sluitende definities te geven van begrippen als beschikking, wet, besluit van algemene strekking, rechtshandeling naar burgerlijk recht, enz. ${ }^{51} \mathrm{Nu}$ kan de wetgever natuurlijk wel trachten definities te formuleren. Opgemerkt dient dan, dat wettelijke definities een hachelijke aangelegenheid blijken als daarmee bevoegdheidsafbakeningen worden beoogd. Gegeven definities blijken vaak niet sluitend. Erger nog, zij doen bij starre hantering de werkelijkheid geweld aan. Situaties, handelingen of besluiten worden dan aan de hand van de definities juridisch geëtiketteerd en, afhankelijk van het etiket, worden dan de rechtsmachtgrenzen getrokken. De werkelijke gevolgen die intreden als gevolg van de bewuste situatie, de handeling of het besluit, en die voor verschillende personen heel verschillend kunnen zijn, worden dan waak genegeerd of verwrongen in de schijnwereld van de juridische begrippen-dogmata, vaak notoire juridische ficties.

Deze juridische werkwijze is niet exclusief voor de toepassing van de Wet AROB. Rechtstoepassing geschiedt vrijwel steeds aan de hand van juridische begrippen. Het maken van juridische constructies met behulp van juridische begrippen is wellicht zo oud als thet rechtsbeleven van de mens zelf. Het gebruik maken van deze constructies in de wetenschap als communicatiemiddel lijkt zelfs onvermijdelijk. ${ }^{32}$ Dat ook de rechtstoepasser daarmee dient te werken is - vooral uit oogpunt van gelijke behandeling - wellicht evenzeer nodig. Of echter ook de rechtsmacht zelf aan een rechtsbegrip moet worden ontleend, daaraan als het ware moet worden opgehangen, is minder vanzelfsprekend. Immers, hierdoor dreigt nu juist het risico van ongelijke behandeling, doordar verschillende rechtsgevolgen door eenzelfde etiket worden verbonden.

De bestuursrechtelijke begripsvorming is overigens niet zonder betwisting gebleven, zeker voor zover zij consequenties heeft voor bevoegdheidsverdeling.

Het onderscheid publiekrecht-privaatrecht is vooral de laatste eeuw onder- 
werp van vele studies, ge richt op het vinden van de 'magische lign' tussen beide gebieden. ${ }^{53}$ Uiteindelijk rechtvaardigen deze studies slechts de conclusie, dat magie en wetenschap blijkbaar slecht verenigbaar zijn. ${ }^{\text {5* }}$

Het wetsbegrip in Nederland moet het nog steeds voomamelijk doen met het werk uit 1966 van Böthlingk, dat door zijn overlijden in feite onvoltooid is gebleven. Weliswaar is het boek na zijn overlijden 'afgerond' door zijn leermeester Logemann, maar die bleek daarbij reeds de eerste die enige afstand nam wan de begripsworming wan zijn leerling. ${ }^{55}$

Het beschikkingsbegrip heeft niet alleen kritiek ondervonden voor wat betreft de afbakening met wetgeving (de meer genoemde 'concrete norm' van Belinfante) ${ }^{56}$ maar ook voor die met de overeenkomst (concessie; aanstelling van een ambtenaar) ${ }^{57}$ en voor die met een feitelijke handeling ("rechtstreeks gericht op rechtsgevolg'; "rechtsgevolg beogend "). ${ }^{58}$ De platsbepaling van de beschikking ten opzichte van onrechtmatige overheidsdaden en rechtmatige bestuursdaden heeft minder aandacht gekregen ${ }^{59}$ Zulks valt wellicht te verklaren doordat voor de conclusie, of sprake is van een van beide laatstgenoemde daden, de werkelijke handeling en de (on)toelaatbaarheid daarvan, alsme. de de reële gevolgen meer bepalend zijn dan de juridische typering.

Inderdaad kan worden geconstateerd dat de afbakeningen tussen de diverse begrippen die in de doctrine zijn geformuleerd in de praktijk grote problemen opleveren.

Zo blijken de grenzen tussen wetgeving en rechtspraak te vervagen bij normerende arresten als Lindenbaum-Cohen ${ }^{60}$ en HBU-Saladin. ${ }^{61}$

Ja, zelfs het onderscheid tussen wet en feitelijk besluit devalueert tot juridisch woordenspel, wanneer we kijken naar de zgn. 'lex imperfecta', zoals een wettelijk voorschrift dat een overheidsorgaan verplicht om binnen een bepaalde termijn een beslissing te nemen, zonder aan overtreding van dat voorschrift enige sanctie of ander rechtsgevolg te verbinden. ${ }^{62}$

De - in het bestuursrecht minder vaak voorkomende ${ }^{63}$ - cassatic in het belang der wet roept, gezien het ontbreken van rechtsgevolgen voor partijen, de viaag op naar het onderscheidende criterium tussen rechtspraak en feitelijk besluit.

Bij de afbakening tussen beschikking en wet valt enerzijds te wijzen op de 'Gesetzgebung für den Einzelfall', zoals naturalisatiewetten en goedkeuringswetten voor huwelijk van leden van het Koninklijk Huis ${ }^{64}$, en anderzijds op besluiten van algemene strekking als nota's, circulaires, plannen, planologische kermbeslissingen, enz. ${ }^{6.5}$

Ook het onderscheid tussen bestuurlijke beschikkingen en rechterlijke beslissingen wordt fragiel als we bijvoorbeeld denken aan de benoeming van een woogd. ${ }^{66}$

De grens tussen beschikking en overeenkomst vervaagt niet alleen bij figu- 
ren als concessie-verlening en aanstelling van ambtenaren ${ }^{67}$, maar ook bij de krachtens wettelijk voorschrift geboden voorafgaande besluitvorming van de overheid (en het bestuurlijk toezicht daarop) inzake het aangaan van overeenkomsten ${ }^{\text {tad }}$, alsmede bij het eenzijdig verbreken van uit overeenkomsten ontstane verbintenissen ${ }^{69} \mathrm{En}$ wat in dit verband te denken van de beide "contradictiones in terminis', de 'publickrechtelijke overeenkomst' ${ }^{70}$ enerzijds en de "privaatrechtelijke vergunning'71 anderzijds?

Het onderscheid tussen beschikking en feitelijk besluit wordt in wezen vaak bepaald door de causaliteitsopvatting, de noodzakelijk geachte relatie tussen besluit (handeling) en gevolg. ${ }^{72}$ Daarbij kan dan slechts worden geconstateerd, dat de Afdeling rechtspraak bij de uitleg van het 'gericht zijn op rechtsgevolg' de burger eerder in de kou laat staan dan de civiele rechter bij de causaliteitsuitleg van de onrechtmatige daad ${ }^{73}$, of de strafrechter bij de causaliteitsleer in het strafrecht. ${ }^{74}$

En waar trekken we de grens tussen overeenkomst en feitelijk besluit als we naast de reeds gegeven voorbeelden - denken aan fenomenen als convenant, beleidsafspraak, bestuursovereenkomst, regeerakkoord en politieke- partijafsprak??

De hier gegeven revue zou misschien nog kunnen worden aangemerkt als eern schets van 'grensincidentjes' - zij het vaak van niet geringe omvang. Denken we aan de vaak voorkomende noodsprong in de juridische wetenschap om maar te spreken van rechtsfiguren 'sui generis' ${ }^{76}$, dan wordt al duidelijker dat problemen van meer structurele aard zich aandienen. Nog evidenter wordt zulks, wanneer van twee bestemmingsplannen - beide toch volledig onder dezelfde wettelijke vigeur vallend - het ene wordt bestempeld tot besluit wan algemene strekking en het andere tot een (arob-abele) beschikking, warbij iets vaags als de 'omvang' of de 'samenhang der onderdelen' bepalend is voor de volkomen verschillende rechtsgevolgen (althans voor wat betreft de rechterlijke competentie). ${ }^{77}$

Met name de afbakeningen tussen beschikkingen en feitelijke handelingen, beschikkingen en besluiten van algemene strekking en beschikkingen en rechtshandelingen naar burgerlijk recht geven een veelheid te zien aan nauwelijks te verteren consequenties van een eenmaal door de Afdeling rechtspraak gedane keuze. Zo moet worden geconstateerd, dat besluiten to zgn. feitelijke handelingen, welke handelingen een onrechtmatige daad in civielrechtelijke zin opleveren, toch geen beschikkingen in de zin van de Wet $\mathrm{AROB} z \mathrm{ijn}{ }^{78} \mathrm{En}$ wanneer is een bestemmingsplan nog een zgn. 'postzegelplan' - en dus als beschikking arob-abel - en wanneer niet meer, omdat het een besluit van algemene strekking moet worden geacht? ${ }^{79}$ En hoe valt het de burger duidelijk te maken, dat besluiten met een onmiskenbare 'beleids-impact' toch tot rechtshandelingen naar burgerlijk recht worden bestempeld, zoals voorwaarden (algemene zowel als bijzondere) bij uitgifte van gronden in erfpacht, hoeveel be- 
leid middels die voorwaarden ook wordt gevoerd? ${ }^{80}$

Ik zie af van verdere voorbeelden. Andere werden reeds gegeven en het streven naar een enigszins representatief overzicht zou een volledige collegecyclus wereisen. ${ }^{81}$

Het voorgaande lijkt me reeds rijkelijk voldoende on de vraag op te werpen, of we met de 'Begriffsgesetzgebung' in artikel 2 Wet AROB wel recht doen wedervaren aan de werkelijke consequenties die voor de burger (kumnen) voortvloeien uit een bepaald overheidshandelen of -beshuten. Aldus kom ik terug naar de voorvraag, of deze handelingen en besluiten juridisch eigenlijk wel te definiëren zijn. In definities bovendien, die gericht zijn op rubricering ten behoeve van de rechtsmachtbepaling: het voorzien van handelingen en besluiten van juridische etiketten, ten einde ze te kunnen onderbrengen in vakjes die door onderscheidene rechters of beroepsinstanties worden beheerd. Daartoe is veelal nodig, dat de definiëring en rubricering ondubbelzinnig is: iets is of een wet of een rechterlijke uitspraak, of een bestuursbeschikking, of een rechtshandeling naar burgerlijk recht, of een feitelijke handeling, of een besluit van algemene strekking. Het onderscheidend vermogen, en daarmee het nut van definiëring en rubricering voor rechtsmach tverdeling, zou immers verloren kunnen gaan als meerdere typeringen van éen en hetzelfde handelen of besluiten mogelijk zouden blijken; als een bepald besluit bijvoorbeeld zowel zou moeten worden aangemerkt als: en beschikking, en rechtshandeling naar burgerlijk recht, en besiuit van algemene strekking, en wet. Leidt de 'of-óf'benadering echter niet in vele gevallen tot onrechtvaardige gevolgen? Zou het niet verkieslijker zijn om wat meer distantie te nemen van het onvolkomen juridische begrippenapparaat en wat meer aansluiting te zoeken bij de - voor mijn part onjuridische --werkelijkheid? Zou de juridische begripsbooefening niet wat meer moeten gaan denken in termen van 'èn-èn'; erkennend, dat één en hetzelfde overheidsbesluit meendere aspecten kent, die zich in meerdere juridische kwalificaties laten vertalen, als we zien naar de reële gevolgen voor de éne dan wel de andere burger? ?a

Ja, zelfs mag daarbij het ter discussie stellen van het veronderstelde onderscheid tussen publick-en privaatrecht niet worden geschuwd.

Analyse van alle denkbeelden over dit onderscheid levert eigenlijk niet mér op, dan dat bij het publiekrecht, bij overheidsbesluiten, steeds het aspect van 'algemene- belangenbehartiging' kan worden onderkend. ${ }^{83}$ Maar is het algemeen belang niet inherent aan alle recht, ook het strafrecht, verbintenissenrecht, familierecht, enzovoort (zij het in de ene sector pregnanter dan in de andere), en is miet het handelen van vele private natuurlijke en rechtspersonen vaak ook (althans mede) ingegeven door overwegingen van algemeen belang? Zelfs de wetgever houdt hier rekening mee. ${ }^{84}$ 
Als laatste bolwerk woor het onderscheid zou nog gedacht kunnen worden an het gegeven, dat woor de overheid uitsluitend het algemeen belang maatgevend mag zijn (zij het witeraard in de context van de afweging van alle in aanmerking komende belangen, waaronder in woorkomend geval ook strikt particuliere). Zulks kan worden erkend, waardoor overigens meteen de fictie achter het onderscheid tussen een overheid, optredend 'alls zodanig' of 'op gelijke voet als een privat persoon' wordt opgeblazen. Inderdaad kan worden gesteld, dat het kopen van potloden door de overheid een keuze impliceert, dat voor dat geld geen kanonnen worden gekocht. Maar waarom dan de particuliere stichting, die uitsluitend ideële doeleinden van puur algemeen belang in haar doelstellingen kent, gerekend tot de sfeer van het privaatrecht? ${ }^{85}$

Wat rest de overheid voor bijzonders uiteindelijk meer dan de typische overheidsmacht, waarvan de verhouding tot het recht immer gespannen is geweest? ${ }^{86}$

In ieder geval kan worden geconcludeerd dat aan alle overheidsbesluiten en -handelingen steeds een aspect van algemeen belang te onderkennen valt, soms sterker, soms zwakker. Zulks geldt dus voor wet, beschikking, rechterlijke uitspraak, besluit van algemene strekking, ja zelfs 'privaatrechtelijke' rechtshandeling en feitelijke handeling. Maar onder de noemer 'algemeen belang' gaat meestal een rijke verscheidenheid aan belangen schuil, waaronder ook afweging van particuliere belangen ${ }^{87}$ We kunnen de in die besluiten samengevatte (afweging van allerlei) belangen onderscheiden; ze zijn als het ware te splitsen naar abstracte en concrete groepen van personen. ${ }^{8 \otimes}$ Het besluit heeft daardoor vaak ook onderscheiden feitelijke gevolgen naargelang de door dat besluit getroffen personen. ${ }^{89}$

Bij samengestelde besluiten worden in de jurisprudentie ${ }^{90}$ nog wel eens pogingen gedaan tot splitsing; splitsing in het besluitencluster zelf dan wel te verstaan. Aan deze problematiek en de daarmee samenhangende kwestie van splitsbare of onsplitsbare wilsverklaringen zal ik hier voorbijgaan. ${ }^{91}$ Het onderwerp dat ons vandaag bezighoudt is niet de splitsing van (samenthangende) besluiten zelf, maar splitsing in de (rechts)gevolgen die uit een bepaald ongedeeld besluit of handelen voortvloeien voor de verschillende personen, die dat besluit regardeert.

Ook is dus in dit kader niet zo interessant de - overigens boeiende - materie van het 'oplossen van besluiten', de 'oplossingstheorie" 92 of - beter-de "ketentheorie". ${ }^{93}$ Deze theorie is door met name de Afdeling rechtspraak noodgedwongen ontwikkeld om bij een reeks elkaar opvolgende besluiten te vermijden, dat over én of meer daarvan de burgerlijke rechter, en over andere zij zelf tot oordelen geroepen zou zijn, dan well dat zij zelf herhaaldelijk tot oordelen zou worden geroepen bij iedere schakel in dit besluitwormingsproces. Het is verleidelijk om hier wat langer stil te staan bij dit andere produkt van 
juridische begripsvorming, waardoor scheidslijnen worden getrokken tussen meerdere rechtsbeschermingsintanties. ${ }^{94}$ Daarbij moeten immers merkwardige consequenties worden getrokken, zoals de consequentie, dat aan een besluit van gedeputeerde staten, waarbij een raadsbesluit tot het aangaan van een bepaalde koopovereenkomst wordt goedgekeurd, het beschikkingskarakter moet worden ontzegd. Zo'n goedkeuringsbesluit, dat toch evident wordt gehanteerd uit oogpunt van besturlijk toezicht, moet daartoe dan worden aangemerkt als 'zich oplossend in een rechtshandeling naar burgerlijk recht' (i.c. de koopovereenkomst). ${ }^{95}$

Verdere oprispingen in dit verband zal ik evenwel bedwingen, omwille van het kader van mijn betoog.

Centraal immers in deze beschouwing is de kwestie van juridische benoeming en rubricering - zeg etikettering - van één en hetzelfde, in zich ongedeelde en ondeelbare bestuursbesluit of bestuurshandeling ten behoeve van rechtsmachtverdeling. De huidige rechtsmachtverdeling vragat als gezegd om ondubbelzinnige etikettering, om te voorkomen dat meerdere verschillende rechters over één en hetzelfde handelen of besluiten tot oordelen worden geroepen, met misschien zelfs wel tegenstrijdige uitspraken. ${ }^{96}$

Gelukkig stelt de civiele rechter zich in dit proces zeer volgzaam op: het oordeel van de bijzondere instantie over de eigen bevoegdheid wordt, zeker door de Hoge Raad, wrijwel steeds (of zelfs 'steeds' zonder "vrijwel"?) overgenomen. Als ouder voorbeeld kan worden gewezen op de bevoegdheidsafbakening tussen de raden van beroep (Centrale Raad van Beroep) en de civiele rechter in het Willemse-arrest. ${ }^{97}$ Meer recent kan worden gewezen op de knieval van de Hoge Raad voor de Afdeling rechtspraak, dat aanschrijvingen inzake politiedwang dienen te worden aangemerkt als 'arob-abele' beschikkingen. ${ }^{98}$ Voorts dient vermelding de stellingname, dat naast de schorsings-/voorlopige-voorzieningsuitspraken van de Voorzitter van de Afdeling rechtspraak op grond van artikel 80 Wet op de Raad van State voor een tussenkomst van de President in kort geding in principe geen plaats meer is. ${ }^{99}$ Dit alles ligt in de lijo van de pragmatische opvarting, dat op het gebied van rechtsbescherming tegen de overheid de civiele rechter moet worden gezien als een noodrechter, die terugtreedt als zijn diensten niet meer nodig zijn, omdat hij reeds genoeg te doen heeft, zoals de ex-President van de Hoge Raad het in 1976 vertolkte. 1 wo

Maar de Afdeling rechtspraak en haar Voorzitter maken het de burgerlijke rechter wel moeilijk bij deze terugtred. Zo huldigt de Hoge Raad nog immer onverkort de opvatting, dat de competentie van de burgerlijke rechter ten aanzien van bestuurlijk handelen wordt bepaald door het recht, waarin de eiser vraagt om beschermd te worden, het petitum, (leer van het objectum litis) en niet door de aard van het recht, waarop verweerder zijn verweer grondt (leer van het fundamentum petendi). ${ }^{101}$ Deze opvatting wordt echter - waarschijn- 
lijk noodgedwongen - door de Afdeling rechtspraak niet gedeeld, die nagenoeg onverbloemd kiest woor de leer van het fundamentum petendi. ${ }^{102} \mathrm{Com}$ petentieconflicten lijken hierdoor onvermijdelijk. Dit blijkt bijvoorbeeld, als de Hoge Raad te kennen heeft gegeven dat de burgerlijke rechter zich niet in mag laten met verkiezingsafspraken ${ }^{103}$ en de Afdeling rechtspraak deze afspraken onomwonden tot overeenkomsten bestempelt. ${ }^{104}$ En de opvatting van de Hoge Raad, dat een werkeersbord een beschikking is ${ }^{105}$, wordt door de Afdeling ontkend met de mededeling dat we hier met een besluit van algemene strekking wan doen hebben. 100

En hoe valt de (beperkte) op artikel 2 RO berustende competentie-opvatting van de Hoge Raad ${ }^{107}$ staande te houden bij een vaste Afdelingsjurispridentie, die alle op rechtsgevolg gerichte bestuursbesluiten die niet berusten op een publiekrechtelijke (wettelijke) bewoegdheidsgrondslag nagenoeg automatisch bestempelt tot 'rechtshandelingen naar burgerlijk recht' 108 ? Het moet wel problemen geven, wanneer de civiele rechter alleen rechten, die door artikel 2 RO worden beschermd (voornamelijk vermogensrechten) tot zijn werkterrein rekent, terwijl de Afdeling rechtspraak stelt dat iedere (rechts-?)handeling die niet in publiekrechtelijke wetgeving haar bevoegdheidsgrondslag vindt een rechtshandeling naar burgerlijk recht is.

Niet alleen terminologisch, ook inhoudelijk zijn verschillen van inzicht aan te wijzen, ook al tracht de Hoge Raad zulks zoveel mogelijk te vermijden. zoals werd opgemerkt bij de aanschrijwingen inzake politiedwang. ${ }^{109} \mathrm{Nog}$ steeds echter bestaan duidelijke verschillen van opvatting, zoals bij het reeds aangehaalde 'uitwegvergunningenstelsel', door de Hoge Raad toelaatbaar geacht, doch volgens de Afdeling rechtspraak in strijd met de wet. ${ }^{110}$ Een ander voorbeeld zagen we bij de verkiezingsafspraken. ${ }^{111}$ En achtte de Hoge Raad in het zogenoemde Krusemann-arresi ${ }^{112}$ een afspraak tot financiële tegemoetkoming voor gemeentelijke medewerking tot woonruimte-onttrekking well verbindend - en dus rechtsgevolgen implicerend -, in een vergelijkbaar geval verklaarde de Afdeling een dergelijke afspraak niet gericht op enig rechtsgevolg. ${ }^{16}$

Met vele andere voorbeelden zou deze lijst kunnen worden aangevuld, maar het lijkt zinvoller om stil te staan bij de vraag naar het waarom van deze verschillen. Het is niet aannemelijk, dat de Afdeling als een soort hogere rechter ${ }^{114}$ an de Hoge Raad de les wil lezen. Waarschijnlijk kan-althans in vele gevallen - niet anders worden beslist dan de Afdeling doet, wil zij de (in wezen onmogelijke) eigen competentie-grondslag ('beschikking" in de zin van de Wet AROB) inhoud trachten te geven. Zijn we daarmee echter, gezien de ook bij het begin van deze rede gegeven voorbeelden, niet op een gevaarlijke weg? Een weg overigens, die werd aangegeven niet door de Afdeling rechtspraak zelf, maar door een wetgever, in het bijzonder een regering, die een overtrok- 
ken vertrouwen stelde in de juridische dogmatiek, begripsworming en rubicew ring ${ }^{15}$ ? Een ventrouwen, dat misplatst kan bljken, als blikt, dat rubriceringen falen. En bij alle rubrieken rijzen abakeningsproblemen van principiele aard, waardoor de rubriceringen zelf twijtelachtig worden, zoals we reeds hebben gezien.

Zow het, zo kan men zich afvagen, niet veel meer recht doen aan de werke lijkheid, als de rechtsmacht ten aranzien van overheidshandelingen of besluiten afhankelijk zou worden gesteld van de werkelike gevolgen voor de daardoor getroffen personen, in plats van een afhankelik stellen van die rechtsmacht van het etiket dat onwille van de bepaling van die rechtsmacht nu wel moet worden toegekend aan dat overheidshandelen of -besluiten?

Dit uitgangspunt van de rechtsbescherming van de persoon, met de consequenties welke deze ondervindt van een bepaald handelen of een bepaald besluit, past binnen een rechtsopvatting die iedere persoon-doch ook uitsluitend personen - erkent als subject binnen het recht. ${ }^{16}$ De gevolgen kunnen per subject verschillen; het recht dient de mogelijkheid te bieden daarmee rekening te houden bij het zoeken naar het evenwichtspunt tussen algemene, noodzakelijk objectiverende, rechtszekerheid en individuele, noodzakelijk subjectiverende, rechtvardigheid. ${ }^{117}$ Zulks brengt enerzijds met zich mee, dat niet alle muance-verschillen juridisch kunnen worden gehonoreerd; watr nodig en mogelijk dient anderzjids zulks evenwel niet letterlijk per definitie onmogelijk te worden gemaakt door een juridisch etiket dat op het betreffende handelen of het bewuste besluit wordt geplakt en dat exclusief bepalend is voor de rechismacht.

Bezien we in dit verband de noodzaak van het etiket 'beschikking' voor de rechtsmacht van de $A R O B$-rechter eens wat nader, dan valt op die noodzaak mijns inziens weel af te dingen.

Bif het onderscheiden natr de gevolgen van ecn overheidsbesluit woor personen of groepen van personen hoort mijus inziens minder belangrijk te zijn of die gevolgen ook workelijk beoogd zijn; of de handeling of het bestuit in deze zin op die gevolgen is gericht. ${ }^{118}$ Immers, de overheid heeft tot tak de beharti. ging van alle belangen, die aan particuliere personen of groepen niet kummen of mogen worden overgelaten of toevertrouwd. 19 Voor alle gevolgen van die belangenbehartiging, beoogd of niet, dient de owerheid volledig de verantwoordelijkheid te dragen. Dit impliceert, dat in de beschikkingsdefinitie van de Wet AROB het element 'gericht op rechtsgevolg' een te missen a lement mag worden genoemd.

Het element 'schrifteligk' in deze definitie heeft uitsluitend betekenis voor het bewijs en is derhalve evenmin essentieel, ${ }^{20}$ 
Zeer ruim is het element 'besluir" in de definitie. "21 Zeker wanneer we aannemen, dat achter elke handeling expliciet of impliciet een besluit schuilgaat ${ }^{122}$, kan de conclusie worden getrokken, dat in dit element van de beschikkingsdefinitie geen reële beperking van de rechtsmacht zit opgesloten, temeer niet door de uitbreiding die artikel 3 geeft (voor weigeringen om te besluiten).

Beperkingen van de rechtsmacht zijn eigenlijk ${ }^{123}$ pas te vinden in thet tweede lid van artikel 2: Uitgezonderd worden daar de $\mathrm{zgn}$. besluiten van algemene strekking en de rechtshandelingen naar burgerlijk recht.

Onder 'besluit van algemene strek king' zou men kunnen verstaan 124: "Teder besluit, voorzover het impliceert de behartiging van algemene belangen in algemene zin; dat wil zeggen, ten aanzien van abstracte personen of groepen van abstracte personen'. Een besluit valt dus niet aan te merken als een besluit van algemene strekking doch als een beschikking, voor zover het in het kader wan de algemene-belangenbehartiging een bijzonder rechtsgevolg impliceert ten aanzien van een concreet persoon of een groep van concrete personen.

Hieraan kan de dimensie worden toegevoegd dat over algemene gevolgen voor rechtsposities in het algemeen de in anmerking komende volksvertegenwoordiging het beslissende woord dient te hebben - en zeker niet de rechter. Bij geschillen over bijzondere gevolgen voor rechtsposities van bijzondere personen hoort het finale oordeel evenwel bij een onafhankelijke rechter. ${ }^{125}$

Voor zover dus een besluit algemene belangen in algemene zin behartigt, dient aan eenieder de toegang tot de rechter te worden ontzegd. Ik keer mij dan ook tegen de gedachte dat steeds een rechts(in)gang bij de rechter zou moeten worden gegeven in alle zaken met bovenpersoonlijk of ideëel belang, inclusief 'algemeen belang'. ${ }^{125}$ Hier behoort de volksvertegenwoordiging het beslissende woord te behouden. Laten we dit systeem los, dan zal elke politieke discussie nog eens worden herhaald in de rechtszaal, iets waar het naar mijn smaak - en ik sta hierin niet alleen ${ }^{127}$ - de laatste tijd toch reeds te veel op begint te lijken.

Echter, voor zover datzelfde besluit tevens een bijzonder gevolg teweeg. brengt voor een concreet persoon of een groep van concrete personen, dient over dat gevolg de deur naar de rechter open te staan.

Wélke rechter dat dan zou moeten zijn, is vers twee. Volgens het huidige systeem hangt dat weer af van een begrip, nl. 'rechtshandeling naar burgerlijk recht'. ${ }^{128}$ Het ziet er niet naar uit, dat aan deze gekunstelde scheiding van rechterlijke competenties anders een eind kan worden gemaakt dan òfwel doordat de Hoge Raad alsnog overgaat op de versmade opvatting van Zonder* land ${ }^{129}$ inzake de exclusieve bevoegdheid van de burgerlijke rechter bij - zegalle vermogensrechtelijke aangelegenheden, of door een verregaande integratie van geschillenbeslechtende instanties. ${ }^{130}$ 
Zien we even af van dit afzonderlijke probleem, dan komt de door mij voorgestane constructie in wezen neer op een voorstel tot schrapping van het gehele artikel 2 van de Wet Administratieve Rechtspraak Overheidsbeschikkingen.

Het accent kan dan volledig komen te liggen op artikel 7 van die wet, dan -voor zover hier van belang - te lezen als: 'De natuurlijke of rechtspersoon, voorzover die door een overheidsbesluit of -handeling in zijn persoonlijk belang is getroffen (anders dan in enig burgerlijk recht), kan daartegen beroep instellen bij de Afdeling rechtspraak van de Raad van State.' Aldus komt de nadruk dan geheel te liggen op het wel of niet in een eigen persoonlijk belang ${ }^{1: 11}$ getroffen zijn door enig overheidsbesluit of enige overheidshandeling.

Hierbij dient evenwel te worden bedacht, dat de Afdeling rechtspraak thans het element 'rechtstreeks in zijn bellang getroffen' in artikel 7 , lid 1 , Wet AROB zeer ruim uitlegt. ${ }^{1.32}$ Daaraan is niet vreemd het - door de Tweede Kamer afgedwongen - schot voor de boeg van de toenmalige Minister van Justitie, dat bij een enge interpretatie wetswijziging zou worden overwogen. ${ }^{133}$ Men kan zich daarbij afvragen, of het onderscheid tussen kwesties over belangen, te beslechten door vertegenwoordigende lichamen, en kwesties over belangen, te beslechten door met rechtspraak belaste instanties, wel voldoende in het oog werd gevat. Verschillende voorbeelden die ik in her begin van mijn rede gaf van zeer grote coulantie van de $\mathrm{AROB}$-rechter ten aanzien van de ontwankelijkheid van belangengroeperingen, dienen tegen deze achtergrond te worden bezien.

Als gezegd, een aspect van het algemeen belang is inherent aan elk overheidsbesluit. Dit aspect behoort niet aantastbaar te zijn door een rechter, behou dens bij aperte willekeur van de overheid. ${ }^{134}$ Eventuele grieven uit hoofde van dit aspect zouden niet-ontvankelijk behoren te worden verklaard. De algemene-belangafweging behoort immers niet tot de competentie van de rechter. ${ }^{135}$ Onder omstandigheden, met name bij beslissingen die overwegend belangrijke gevolgen hebben voor abstracte personen of abstracte groepen van personen, kan zulks betekenen, dat vernietiging van het betreffende besluit bij voorbaat uitgesloten zou moeten worden geacht (behoudens bij aperte willekeur).

Zulks zou de gang naar de rechter door een bijzonder in enig persoonlijk belang door datzellde besluit getroffene echter nog niet geheel zinloos hoeven te maken. Vergoeding van het door hem geleden nadeel zou mogelijk dienen te blijven in iedere voor toewijzing daarvan vatbare vorm. ${ }^{136}$ Ja, wat zodanige mogelijkheid tot op heden ontbreekt, zou zij (in algemene zin) geboden dienen te worden. Dit betekent, dat ter zake van alle rechtmatig te achten overheidshandelingen en -besluiten, waardoor iemand bijzonder in zijn per soonlijk belang wordt getroffen, aan deze een actiemogelijkheid ter zake van bestuurscompensatie zou dienen te worden geboden. ${ }^{137}$ 
Een woorbeld kan wellicht de zojuist in abstracto ontwouwde gedachten illustreren. Stel, dat een gemeenteraad besluit om met de NS een overeenkomst aan te gaan over de reconstructie van het stationsgebied. ${ }^{138}$ De NS en de gemeenteraad zouden zich dan na het sluiten van de overeenkomst - de belang. rijkste keten uiteraard in dit besluitvormingsproces - ter zake van de uitleg van die overeenkomst, of eventuele niet-nakoming ervan e.d., tot de burgerlijke rechter dienen te wenden.

Als echter een regelmatig NS-reiziger vreest ongemakken te zullen ondervinden door die reconstructie, zou hij met zijn klachten niet bij enige rechter dienen aan te kloppen, maar bij de gemeenteraad (of, eventueel, bij de Kroon met een verzoek om 'spontane' vernietiging, als de kwestie hem zo hoog zii). ${ }^{139}$ Hier is immers geen sprake van een eigen, persoonlijk belang, doch van een algemeen belang, in beginsel eenieder gelijkelijk regarderend.

Een vergunninghouder voor een bloemenkiosk tenslotte, die als gevolg van de reconstructie ziet aankomen, dat voor zijn nering in de toekomst geen plats meer zal zijn, zou zich weer wél tot een rechter (in casu echter de Afdeling rechtspratak) behoren te (kunnen) wenden. Daarbij zou hij dan evenwel niet om vernietiging van het besluit moeten kunnen vragen; wel om bestuurscompensatie.

Ik begon deze rede met enkele voorbeelden uit de jurisprudentie wan de Afdeling rechtspraak en haar Voorzitter. I $\mathrm{k}$ wil ook besluiten met enkele voorbeelden. Voorbeelden, die aangeven, hoe de door mij verdedigde nuancering van werking van overheidsbesluiten gestalte zou kunnen krijgen voor de rechtsmachtverdeling.

Op 14 december 1981 bestempelde de Voorzitter van de Afdeling rechtspraak een besluit van $B$ en W van Drunen, om van elke ingeschreven woningzoekende voor een huurwoning een waarborgsom te vragen, tot zowel een besluit van algemene strekking als een rechtshandeling naar burgerlijk recht. ${ }^{140}$ Deze concessie aan de meerzijdigheid van én en hetzelfde overheidsbesluit kan voor de competentie-verdeling nog betrekkelijk ongevaarlijk worden geacht. De AROB-rechter is immers ten aanzien van geen van beide bevoegd. Bovendien valt te bedenken dat volgens artikel 2 Wet $A R O B$ de begrippen "besluit van algemene strekking" en "rechtshandeling naar burgerlijk recht" elkaar niet per definitie uitsluiten.

Anders is zulks evenwel ten aanzien van de begrippen 'beschikking' en 'rechtshandeling naar burgerlijk recht'. Niettemin vallen ook uitspraken aan te wijzen, watrbij én en helzelfde besluit als zowel het een als het ander werd getypeerd. De Kroon onder vigeur van de Wet-BAB ging hierin reeds voor. Het Rijk weigerde om de Pieterskerk te Leiden (een beschermo monument) kosteloos in eigendom te aanvaarden. De Kroon achtte dit weigeringsbesluit niet alleen een privatrechtelijke handeling, maar tevens een beschikking in 
de zin van de Wet-BAB. De eigenaar bleef eigenaar van een monument in de zin wan de Monumentenwet en derhalve gebonden aan de verplichtingen, door die wet opgelegd. ${ }^{241}$ Te bedenken valt hierbij, dat onder de Wet-BAB de begrippen 'beschikking' en 'rechtshandeling naar burgerlik recht' elkaar niet met zoveel woorden uitsloten ${ }^{142}$, al was zulks wel de bedoeling van de wetgever. ${ }^{143}$

De Afdeling rechtspraak volgde met de in het begin van deze rede weergegeven uitspraak inzake de Valkenburgse kwestie. ${ }^{144}$ Het besluit van B en W hield volgens haar een weigering in om een rechtshandeling naar burgerlijk recht te verrichten, doch moest tevens worden aangemerkt als een beschikking in de zin van de Wet-AROB.

Nog éenmaal besliste de Afdeling in soortgellike zin. Dit gebeurde in de kwestie van de Groningse waterleidingconcessies. ${ }^{145}$ Hoewel eerst werd overwogen, dat de betreffende weigeringsbesluiten zich oplosten in de uitoefening van het aan de gemeente toekomende eigendomsrecht, werd appellante toch ontvankelijk geacht. De gemeente had volgens de Afdeling niet alleen de eigendom van de betreffende zaken, maar het gemeentebestuur was krachtens zijn algemene publieke bestuurstaak ook belast met de zorg om die zaken zo goed mogelijk aan hun openbare bestemming te doen beantwoorden. De aangevochten besluiten werden geacht in overwegende mate deel uit te maken van het door verweerders gevoerde beleid in het kader van de op hen als overheidsorgaan rustende taak. Daaruit volgde, dat de bestreden besluiten mede inhielden rechtshandelingen, gericht op andere dan burgerrechtelijke gevolgen, en wel beschikkingen in de zin van de Wet AROB.

De Afdeling heeft evenwel deze gedurfde jurisprudentie verder geen gestalte meer gegeven. Wellicht was hier sprake van de bekende éne zwaluw en de even bekende witte raaf. Uitspraken als deze komen ook wel te zeer op gespannen voet met de tekst van artikel 2 Wet $A R O B$, watin als gezegd de begrippen 'beschikking' en 'rechtshandeling naar burgerlijk recht' als elkaar witsluitend zijn geformuleerd. Slechts wetswijziging lijkt hierin verandering te kunnen brengen. Bovendien zit de Afdeling rechtspraak al evenmin on werk verlegen als de burgerlijke rechter, ${ }^{146}$

Dames en heren leden van de wetenschappelijke staf van de juridische faculteit: dames en heren studenten,

Het onderwijs volgens het 'Maastrichtse' model gaat in aanpak uit van probleemgestuurd thematisch onderwijs, hetgeen volgens wat ik zojuist heb gezegd mijns inziens meer aansluit bij de werkelijkheid dan een onderwijs dat vertrekt vanuit een juridische begrippen-dogmatiek. Men zou zich daarbij 
kunnen afvragen, of de communicatieve functie die aan juridische begripsworming met name voor wetenschapsdoeleinden moet worden toegekend op deze wijze niet veloren gaat, met andere woorden of de bij ons afstuderende studenten dezelfde taal zullen spreken als de studenten die aan andere faculteiten afstuderen. Ik meen dat dit risico enerzijds in het oog moet worden gehouden, doch anderzijds niet moet worden overschat. Ook de vormgeving van het derde en vierde studiejaar, welke wormgewing gestalte begint te krijgen, leent zich mijns inziens tot enerzijds het bijbrengen wan het juiste evenwicht tussen begripsvorming als noodzakelijke bagage voor de communicatie en anderzijds tot relativering van die begripsworming door voortdurende confrontatie met de feitelijke werkelijkheid in de praktijk. De vormgeving van de eerste twee jaren biedt mijns inziens alle grond woor het vertrouwen dat een realisering van deze doeleinden binnen de grenzen van het haalbare ligt. 
1. Ald. rechtspraak RvS 8 juli 1977, B BS, V, blz, $82 \mathrm{~h}$.

2. Vz. Afd, rechtspraak RwS 28 tebruan 1978, tB/S, V. biz. 23, Soortgelijk: V. Ald rechtspraak RvS 6 januari $1978, \mathrm{AB} 1978.160$.

3. Vz. Afd, rechtspraak RWS 11 april 1979, IBS, II, ar. 122.

4. Afd. rechtspraak RuS 8 januari $1981, \mathrm{BBS}, \mathrm{IV}, \mathrm{nr} .62$.

5. Afd. rechtspraak RWS 24 noveruber 1977 , tBiS, IV , bla 33

6. Vz. Afd. rechtspraak RWS 16 augustus $1979,1 \mathrm{~B} / \mathrm{S}, \mathrm{VI}, \mathrm{m}, 73$.

7. Afd. rechtspraak RwS 12 juni 1980, tB/S. MII. mr. 196.

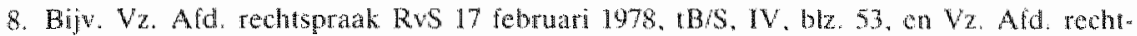
spraak RwS 12 april 1979, tB/S, VII, nr. 65.

9. Vgl. bijv. HR 2 februari 1966, NJ 1966, 415 (Onteigening Hoogeloon); KE 29 oknober 1969, S. 488, Bouwrecht 1969, bl. 764 (Martinusstichting Nijnegen - spontane vernictiging); KB 29 oktaber 1975, S. 600, De Gemeentestem 1975, blz. 476 (Soest-eveneens spontane vernietiging); de beide KB"s van 20 jamuari 1971, resp. mrs. 59 en 60 . De Nederlandse Gemeente 1972, bliz. 335, AB 1971, 153 en Bowwrecht 1971, blz. 193 (de in adminisiratief beroep gedane uitspraken inzake de bouwverordeningen van Lichtenworde en Nijmegen), alsmede Afd. rechtspraak RwS 1 september 1977, tB/S, V, blz. 140 (Van Kan-Maastricht). Zie voorts de noten 11,12 en 14 .

10. Add. rechtspraak RwS 2 oktober 1978 , IB/S, V, nr. 106, Voor een wergelljkbar gewat zie Ald. rechtspratak RvS 28 maart $1981, t B / S, V$, nr. 222.

11. Zie de in noot 9 geciteerde uitsprak inzake Van Kin - Maastricht, alsmede o.a. Afd. rechtspraak RwS 8 juni 1978, Ars Aequi 1978, blz. 574 (De Biltse uitwegkwestic).

12. Aff rechispraak R4S27 maat 1981, 1B/S, V, nr. 221.

13. Men zie de utrslag van te in noot 9 en noo 11 gecheerde. Afdelingsjurisprudentie.

14. Add. rechtspraak RwS mei 1981, AD 1981, 391.

15. Vz. Afd. rechtspraak RwS 10 januari 1978, IBS, V, blz. 202.

16. V2. Afd. rechtspraak RwS 20 april 1978, AB 1978, 405 (vereemoudigd afgedarn!).

17. Afd. rechtspraak. RvS 10 december $1979, \mathrm{LBS}, \mathrm{V}, \mathrm{nr}, 153$.

18. VZ. Ald. rechtsprak RWS 29 juli 1981, $\mathrm{B} / \mathrm{S}, \mathrm{V}, \mathrm{V}, \mathrm{nr}, 238$.

19. Vz. Afd. rechtspraak RWS 3 augustus $1978,1 \mathrm{~B} / \mathrm{S}, \mathrm{V}$, blz 331.

20. Afd. rechtspraak RwS 23 oktober 1979, 1BS, W, nr. 145 . 


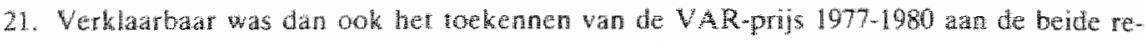
dacteuren vande omvangrijke losbladige jurisprudenthebundel $A R O B$ (thans reeds acht delen) wan Samsom (vgl Geschrift VAR LXXXX, blz. 35-37).

22. Zeer helder: J.A. Borman, Wet administratieve rechtspraak overheidsbeschikkingen: in: Ars Aequi 1975, b12. $657-669$.

23. Overigents wordt op deze rechtsgebieden de rechtsmacht ook niet exact aan de hand van reikwijdte wan wetten of rechtsgebieden toegckend en is wak aan verschillende rechters in Gerl en dezelfde wet of op en en hetzelfde rechtsgebied rechtsmacht verleend. Voor een owerzicht wn suggesties tot herschikking zie het Rapport Bevoegdheidswerdeling Administratieve Rechtsprák, opgenomen in Trema-special 1980-2 (Rapport van de Werkgroep In. ventarisatie Bevoegdheden Administratieve Rechters van de Afdeling Administratieve Rechtspratak van de Nederlandse Vereniging woor Rechtspraak; de zgn. Werkgroep-Punt).

24. C.W, van der Pot, Nederlandsch besturstecht, Algemeen deel, Samsom, 1932.

25. Onderscheid, dat nog steeds zeer veel, tot overheersende, atrhang windt. Vooral in zwang gekomen onder invloed van L. van Praag. Op de grenzen wan publek-en priwat. recht, 1923 (vermeerderde uilgave 's-Grawenhage 1930).

26. HR 19 januari 1962, NJ 1962, 151. Van vele zijden sterk bekritiseerd, a. door A.M. Donner, Nederlands Bestuurstecht, Algeneen Deel, thitgave 1973, Samsom 1974, ble. 153 154 .

27. Vg. H.A.M. Aattink, Mag de owerheid afwijken van wat zij is overeengekomen?; NIB 1977, blz. 733-7410.

28. Vgl. J. Spier, Onrechtmatige overheidsdaad (m.m.v. H.C. Koetzier); Tjeenk Willink. Zwolle 1983

29. A.D. Belinfante, Kort Begrip van het Administratief Recht; hoofdstuk 3.

30. H.D. van Wijk, De norm is per definitie abstract; Deventer 1971.

31. Algemene bepalingen van administratief recht, Rapport van de commissie wit de Verenging voor Adninistratief Recht inzake algemene bepalingen van administratief rech, vierde, bijgewerkte druk (1973), tweede oplage, H.D. Tjeenk Willink b.v. Alphen aan den Rijn 1980, blz. 5.

32. Idem als vorige noot.

33. A.w, ble, 5, noot 10

3.4. A, w, blz.2.

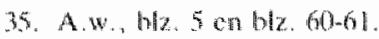

36. Art. 2, lid 1, jo. art. I Wet AROB.

37. Art. 1, 1, atohef. Wet AROB.

38. Art. 1.1, onder a Wet AROB.

39. Art 1.1. onderd, Wet AROB. 
40. Art 1.1, onder e, Wet AROB.

4. Art. 2, lid 1. Wet AROB.

42. Art 2, lid 2, sub a, Wet AROB.

43. Ant 2, lid 2, sub b, Wet AROB.

44. Art 5, sub d, Wan AROB.

45. Art 5, sub j, Wet AROB.

46. Art 5, sub m. Wet $A R O B$.

47. Art. 4 en art 7, lid 1. Wet AROB.

48. Art. 7, leden 1 en 2 ("zijn belang), Wet AROB.

49. Art. 7, leden 1 en 2, Wet AROB.

50. Zie: Parlementaire geschiedenis van de Wet AROB alsmede van de daamee samenhangende wijziging van de Wet op de Raad van State: bew door I.H. van Kreveld en $M$. Scheltema, m.m. . B.J. wait Kersbergen, Tjeenk Willink, Groningen, 1976.

51. Vgl. F.W. ter Spill en A.Q.C. Tak, Onwetmatig bestuur; preadvies voor de Verenging woor Administratief Recht 1981, Geschrift VAR LXXXVI, blz. 11-13.

52. Vgl. A. Komen, Algemene inleiding; in: Nedertands recth in kort bestek; to druk. Kluwer 1983, blz. 28-30.

53. Terminologie, ontleend aan $J$. van der Hoeven, De magische lijn. Verkermingen op de grens wan publick-en priwatrecht; in: Honderd jaar rechtsleven, 1970. Voor een owerzicht wan de gedachtenontwikkelingen zie mijn Overheidsbestuur cn privaatrech, Samsom 1978. blz. 71-76, alsmede D.A. Lubach, Beleidsovereenkomsten, Kluwer 1982, blz. 74-99.

54. Reeds in 1909 constatecrde Kranenburg in zijn dissertatic. dat voor het onderscheid geen wezenlajk onderscheidende elementen te vinden zijn en dat geen essentieel versedil in rechtsgevolg bestat (R. Kranenburg, De tegenstelling tusschen publiek-en privastrecht en de ontwerpen tot regeling der administratieve rechtspraks; Noordhoff. Groningen 1909.

55. F.R. Bothlingk. Het wetsbegrip in Nederland; voltooid door J.H. A. Logemann. Sinhx som. Alpen aan den Rijn: 1966.

56. 2ie noot 29 .

57. Vgl. A.M. Donner, Nederlands bestuursrechi, Agemeen ded; untgave 1973, Sambom 1974 , blz. $304-306$ en blz. $167-168$ (en de in noo 2 op blz. 168 geciterde anteurs).

58. Zie hierover o.a. J.G. Steenbek. Wet administraticve rechsprak overhodsbeschikkin. gen, VUGA-boekerij 1979, biz. $51 \% 60$.

59. Het gecitecrde Rapport ABAR betrekt deze daden zonder nadere loelichting in de beschouwingen over beschikkingen (0.a. blz. 153-157).

60. HR 31 jamuari 1919, NI 1919, 161.

61. HR 19 mei 1967, NI 1967.261. 
62. Un de vele gevallen noem ik als voobeelden art. 53 , fid 1, Ambtenturenwe: 1929,75 , lid 1 . Beroepsuet en art. 33 We op de ruimtelijke ordening.

63. Alleen bij administratieve rechtspraak door de gewone recher. Vergelijkbar is het 2gri. beroep in het belang der wet, worzien in de art. 24 en 25 Ambtenarenwet 1929,43 Beroepswer en in enkele bijzondeve weten. Voor verdere ulteenzettingen zhe Tak-Ten Berge. Nederlards administratiel procesrecht, deel 2, nrs, 1526-1527.

64. Vgt. F.R. Böthingk en J. Glastra van Loon. Het begrip rechtsregel; in: R, M. Themis 1954, blz. $3 \mathrm{c}, \mathrm{w}$

65. Zie hicrover verder min bijdrage Besluiten van algemene strekking; in: RM Themis 1980, blz. 132.162

66. Art. 295 Boek 1 BW. Zie ook bijw. art. 307 Boek 1 (toeziend voogd); 378 Boek 1 (cu* rator); 409 Boek 1 (bewindswoerder) en 14 Fw. (faillissententscurator).

67. Zie noot 57.

68. Vgl mijn Overbeidsbestuur en privaatrecht, Samsom 1978 , hoofdstuk 6 .

69. Zie de in noot 27 geciteerde bijdrage van Aartink.

70. Vgl D.A. Lubach, Beleidsovereenkomsten; Kluwer 1982, alsmede de door hem geciteride auteurs.

71. Reeds KB 11 september 1964, AB 1965, 167. Voorts o.a. Afd. rechtspraak RuS 28 juli 1981, opgenomen in Aantekening onder tB/S, V, nr. 230.

72. Hicrbij dient to worden bedacht, dat deze relatie in het publickrecht wordt bepaald door de strekking wan het objectieve recht, en niet door de subjectieve wil van de betreffende ambtadrager (vgl, noot 122).

73. Zie thans de art. 6.1.9.4 e.w. NBW. Voor titleg van deze artikelen in het licht van de hưdige jarisprudentie (1oerekeningsleer) zie de parlementaire behandeling, weergegeven in Pamementare geschiedenis van het nieuwe Burgerlijk Wetbok; boeken 3, 5 en 6; Studenteneditie, Kluwer 1982, blz. 509-513.

74. Zit met natme HR 20 maart 1970, NJ 1970, 251. Voor uitgebreide beschouwingen zie D. Hazewinkel-Suringa, Inleiding tou de studie van het Nederlandse strafrecht; $8 \mathrm{e}$ druk, be werkt doon J. Remmelink. H. D. Tjeenk Wallink, Alphen aan den Rijn 1981, blz, 122-139.

75. Vgl. nasst het in noof 70 geciteerde werk van Lubach: J. Wessell, Belcidsovereenkonsten en andere asptaken in de publieke steer; preadwies voor de Statstechtconferentie 1977 to Utrecht, uitgave Vakgroep Stats-en administratiefrecht van de juridische faculteit van de R.U. Utrecht 1977 , die de stelling werdedigt dat zelfs partij-en regeerakkoorden voor de recher afdwingbatr (moeten) zijn (blz. 244 e.v.).

76. O.a. bij bestemmingsplannen (Belinfante, Wessel c.at.). Voor kritiek op het dichotome denken door juristen in wit-zwart tegenstellingen, zie J. Wessel, Publiekrechtelijke planolo gische maatregelen op gemeentelijk nivean; bijdrage in De Jurist en de Ruimteligke Ordening; Deventer 1973, blz. 79.

$\mathrm{Vgl}$ meer in het algemeen over de problematiek van juridische begripsvorming en constructie: H.J. van Eikema Hommes, De elementaire grondbegrippen der rechtswetenschap; Kluwer 1972, met rame blz. 7 e.4., alsmede de daar geciteerde auteurs. 


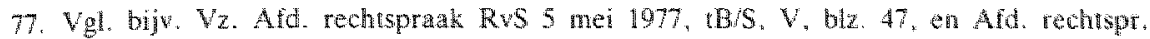
RvS 7 augustus 1978, AB 1979, 215, alsmede 2 oktober 1978, BS, V., nr. 104 (met andere

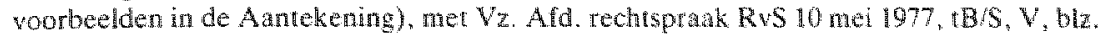
56, en Ald rechrspr. RvS 6april 1979, AB 1979, 490, alsmede B okl. 1980, 1 BSS, V, ni, 199.

78. Vgl. J.B.A.M. ten Berge en F.A.M. Stroink, AROB in vogelvucht; 2e druk, Samsom 1982. blz. 60

\section{Zie noot 77.}

80. Ald. rechispraak RuS 12 januar: 1981, tBS, V, n. 212. Voor verdere voorbectden ze Ten Berge-Tak, Nederlands administratief procestecht, deel 1 , nr. 516.

81. Een uitgebreide selectie wan uitspraken geeft de lostladige wigave Adminstratieve rechtspraak owertheidsbeschikkngen; onder redacte van J.J.M. ten Berge en F.A.M. Stroink, Samsom, onder rubriek V, Beschikking".

82. Vgl het in noot 51 geciteerde preadwies, met name biz. 13

83. Vgl. P.C.E. van Wimen, Recht, belang en rechtsbescherming; VUGA 1981, blz. 280. 295, allsmede de daar geciteerde auteurs, waronder vooral Vegting. Voorts J. Spier, Overeenkomsten met de overheid; a.w., blz. II, en de daar angehaalde schrijwers.

84. Vgl. o.a. ant 6.3.5.1. b NBW. Zie verder de voorbetden gegeven door A.R. Bloembergen, Opnieuw: bestuursrecht en privatrecht. In discussie met P. de Haan, Th. G. Drupsteen en R. Fernhout, Bestuurstech in de sociale rechtsstat. Instrument en wartborg; in: Bouwrecht 1979 , bliz. 369-380.

85. Ook de opvatting, dat de overheid het algemeen belang in zin totaliteit (exclusion) tor haar terrein zou mogen rekenen, kan mij niet overtuigen, gezien de telkens wisselendé inwulling van het begrip "algemeen belang". Hierover uitvoeriger: 5.0 . wan Poelje en C.H.F. Polak, Het begrip "algemeen belang' in de verschillende onderdelen van het administratieve recht; preadvies voor de Vereniging voor Administratief Recht 1950, Geschrift VAR XIX.

86. Vgl, L.J. van Apeldoorn, Inleiding tot de studie van het Nederlandse recht; 17e druk, bewerkt door J.C.M. Leyten, W. E.J. Tjeerk Willink, Zwolle 1972, blz. 15: 'Uitschakeling van de rechtvaardigheidsgedachte uit het techt leidt tot vereenzelving van recht en macht.' Zie voorts de uitvoerige literaturvermelding bij deze atuteurs.

87. Vgl. het in noot 85 geciterde preadwies.

88. Vgl. mijn in noot 65 geciteerde bijdrage, met name blz. 149-152, alsmede P.C.E. van Wijmen, Rech, belang en rechtsbescheming; VUGA 1981 , bly. 419 e.v.

89. Zie vorige noot.

90. Men denke bijw. aan de uitwoerige jurisprudentie inzake bestemmingsplannen. Vgl ook Rappont ABAR, a.w., par, 5.5.1 (me jurisprudentievermalding).

91. Voor op het publiekrecht toegespiste beschouwingen zij verwezen nuar B.C. Punt, Ontwankelikheid en omwang van het berope fegen administratiove beschikkingen: VUGA. boekerij 1975, nr. 77 (ble, 279 e.w), net jurisprudentievermelding.

92. Hierover 0.a. A. de Goede. Oplossing van besluiten; in: De Gementestem 1977, nr. 6471, blz. 405-406. Zie ook E. Brederveld, Een 'waterige oplossing' van besluiten met betrekking tot openbare grond; irr: De Gemententem 1978, n2, 6500, blz. 147-149 
93. Of "integratetheorie": zie min in noot 65 geciterde bijdage, blz. 145

94. Vgl. hierover verder I.G. Stenbeek, Wet administratieve rechtsprak overheidsbeschikkingen, a, w onder andere blz. 74 e.\%.

95. Hierover uitworiger de in noot $92 \mathrm{en}$ in de worige noot geciteerde bijoragen.

96. Doemt her aan de horizon een Conflictentribunaal op, naar model wan het 'Tribunal des Conflits in Frankrijk?

97. HR 26 Juni 1964, NJ 1965, 2.

98. HR 25 november 1977, AB 1978, 194.

99. In hetzdide arrest dat in de vorige noot werd geciteerd.

100. G.J. Wiarda, Administratief-en civielrecht; voordracht in de vergadering van de Ver. eniging voor rechispraak wan 7 mei 1977, opgenomen in NJB 1977, blz 729 e.v.

101. Zie HK 31 december 1915, NJ 1916. 407. Voor latere arresten zie HR 26 matr 1971 , AB 1971,135 (cassatie in het belang der wet), en HR 9 november 1973, NJ 1974, 91.

102. Dit ligl geheel in de hin wam moderne opvattingen, zoals o.a. verkondigd door $\mathbb{M}$. Scheltema, in: Voorlichting over AROB; W. E.J. Tjeenk Wilnk, Zwolle 1976, biz. 28-39.

103. Zie het in moot 101 geciteerde arress van 1971.

104. Afd. rechtspratak RvS 6 september $1982, \mathrm{AB} 1983,114$.

105. HR 4 maant 1958, NJ $1958,300$.

106. Zie VZ. Afd. rechtspraak RwS 30 augustus 1977, HBS, V, blz 137; Vz. Afd. rechispraak RWS 18 december 1979, opgenomen in de Aantekening onder $1 B / S, V$, nr. 153; Add. rechtspraak RUS 15 januari 1981, tB/S, V, nr, 215.

107. Voor een goede uiteenzetting met gedegen bestrijding zie P. Zonderland, Het kort geding, in het bijzonder tegen de overheid; 2e druk, W.E.J. Tjeenk Willink, Zwolle 1972.

108. Vgt bijw. Afd rechtspraak RuS 15 december $1978, \mathrm{tB} / \mathrm{S}, \mathrm{V}$, ni. 113, V2. Ald rechtspratk RvS 25 juni 1980. AB 1980, 450, Adt, rechtspraak RwS 18 september 1980. AB 1981. 148. on Ald. rechisprata RvS 21 september 198j, AB 1982, 22.

169. Zic noot 98

110. Zie nowt 13

111. Zie de noten 203 en 104

112. HR 13 aprill 1962,NJ1964, 366.

113. Afd rechisprak RUS 14 juli 1981, tB/S, V, ar. 231.

114. Te bedenken valt enerzijds, dat gezien de korte beroepstermijn van art. 9 We: AROB de Afdeling rechnprak wrijwel steeds als eerste noet oordelen over omstreden bevoegdlicidskwesties; anderzijds bljift - on dezelfoe reden - het latatse woord in principe atan de civiete recher. 
115. De regering heeft zich niet veel gelegen laten higen atm wadschuwingen van vele zijden. Reeds in 1960 warschuwde H.D. van Wijk tegen de beperkende werking van het beschikkingsbegrip in zijn bijdrage 'Beshiten en hamdelingen', in de zgn. Van der Berg-bundel. Genoemd kan verder worden de vergadering wan de VAR wan 24 januari 1922 , waatbi o.a. I. in "t Veld en B.C. Punt er reds voor plenter on berop open te stelten tegen 'bestuiten en handelingen' in plaals van slechts tegen 'beschikkingen". Ook in het Voorlopig Ver* slag klonk vrees woor beperkende werking wan dit begrip door (stuk 11279 , bl . 3). De Rad van State adviseerde om geen omschrijing van het beschikkingshegrip in de we op te ne. men (advies van 15 mei 1974, Bijl, bij MvA II, bl2. 52). Bepleit werd beroep open te stellen tegen alle beshiten, uirgezonderd besllaten van algemene strekking en rechtshandelingen natar burgerlijk recht. Behartigenswardig is de zinsnede: "Veleet bestaat hier het risico dat zoals de praktijh heeft geleerd een atan de administratiefrechtelighe doctrine ontleende begripsomschrigung zal leiden tot beperkingen welke niet zijn bedoeld. "De regering hield voet bij stuk met het mijns inziens oneigenhije argumen, dat nict was to voorzien tot wetke uitbreiding van de werkingssfeer wan de Wet AROB dit zou leiden, en het mins inziens a cven onzuivere argument, dat hiverover tijdrovend nader overleg met de overige departementen nodig zou zin geweest (Nader rapport, Bijhage bij MvA II, bz. 57).

16. Vgl. LJ. van Apeldoom, Inleiding tot de studie van het Nederlandse recht. $17 \mathrm{e}$ druk, bewerk door J.C.M. Leyten, W.E.J. Tjeenk Willink, Zwolle 1972 , blz. $154-159$ en de daar geciterde literatur.

117. Vgl. M.E. Mayer, Rechtsphilosophie, 3e Aufl, o.a. blz. 79.

118. Anders: J.G. Steenbeek, Wet administrateve rechspratk owerbeidsbeschikkingen; a. W., ble 51-60.

119. Zie mijn Overheidsbestunr en privaatrecht, a.w., ble. 85 a.v.

120. Vgl. Steenbeek, a.w., blz. 41-42; Ten Berge/Stroink, AROB in vogelvluchn, a.w. blz. 54-55, alsmede dez. in hun commentat op de artikelen 2 en 3 We AROB in: Administratieve rechtspraak overheidsbeschikkingen; losbl. uitg. Samsom, blz. $3-4$.

121. Steenbeek, Wet administratieve rechtspraak overheidsbeschikkingen, a.w., blz, 42-46, geeft een beperktere uitleg, hetgeen mijns inziens te verklaren wall uit het feit dat hij het element 'besluit' impliciet koppelt aan 'rechisgevolg' (iets, wat op zichzelf mijns inziens niet hoeft).

122. Hier rijst wel de specifeke problematick wan de 'anbeswil'. Vgl hicrover o.a. Rapport

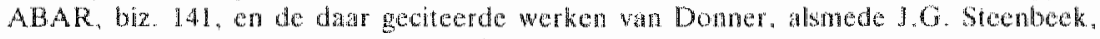
Rechtshandeling en rechtsgewolg. VUCA, 1958.

123. Agezien wordt van de specifieke beperkingen in de ant $1,5,6$ (ind bijlage bij de wet), 7 en 11 . Deze beperkingen blijven hier verder buiten bespreking.

124. Vgl. mijn in noot 65 geciteerde bijdrage, met name blz. $160-162$.

125. Vgl. het in noot 51 geciterede preadvies, met name blz. 49-51.

126. Zoals verdedigd in her in noot 88 gecticerde werk van Yan Wijmen, met name op blz 580 ('gekanalisecrd publick beroep').

127. Ook bijv. CW. Dubbink, Rechter, wetgever, bestuur; in: De Praktijkgids 1980 , blz. $265-266$. 
128. 2ie de elkar witsitende tegenstelling tussen beschkking' en 'rechtohandeling naar burgentik recht' in resp. ast. 2 lid 1. en art. 2 hid 2 , sub b. Wet AROB

129. Wergegeven in zijn in noot 107 geciecrde werk.

130. Voor de recente onlwikkelingen op dit punt beginend met de Werkgroep herziening recherlike organisate (Werkgroep-Wiersma), gevolgd door de Statscommissie Herziening Recherligke Organisatie (aanvankelijk Cie-Ras, thans Cie-Van Zeben), ne haratsubcommissies (Cie-Van Galen en Cie-De Gay Forman), alsmede de door de Afdeling Administratieve Rechtsprakk wan de Nederlandse Vereniging woor Rechtspraak ingestelde zgn. Wemgroep-Pun, zie Ten Berge-Tak, Nederlands administratief procesreche, deel 1 , n. 124-129 (net vermelding der uitgebrachte voorstellen).

131. Hicrover: P.J.J. van Buten, Kringen van belanghebbenden, in het bijzonder in procedures tegen de overhed; Kluwer 1978. ZCer gedocumeneerd, doch met een afwijkende visie: Var Wijmen, aw. (zie noot 88). Vgl ook Ten Berge-Tak, a. w., nr. 351-372.

132. Voor recente wergave van de jurisprduentie, zhe Ten Berge-Tak. a.w., nr. 346-348 en $373 \cdot 379$

133. Bijl. Hand. II, 1974-1975, 11279, 11280, nr. 30, bl. 5. Zie over deze kwestie: P.J.J. wan Buten, Kringen vam belanghebbenden; Kluwer 1978 , blz. $46-48$,

134. Dit begrip is hive bedoeld in de betekenis, gehantecen in Ten Berge-Tak, a.w., nr. 740. 758.

135. Zie noon 125.

136. Vgl. mijn Overheidsbestuur en priaatrecht, a.w., bla, 118 en blz. 339 e.w., in het bijzonder blz. 341; alsmede min bijdrage Financiele compensatie terzake van rechtmatige bestuursdaden; in: Schade lijden en schade dragen, NJB-boekenreeks nr. 6, Tjeenk Willink, Zwolle 1980, biz. 85 e.v., in het bijzonder blz. 88, en J.A.C. van der Gouwe, Onteigening en schadevergoeding bij rechmatige overheidsdaad, losbl. uitg. VUGA-boekerij, blz. I-16e.v. (in hat bijzonder blz. I-18).

137. Zie mijn beide in de vorige noot geciteerde werken.

138. Het voorbeld werd geinspireerd door de kwestie wan de reconstructie van het stationsgebicd mol ongeving te Goes (Vz. Afd. rechespratk RVS2L maart 1978, tB/S, V, blz 246).

139. Op grond van an. 185 gemeentewet (zgn. 'uitokking van spontane vernietiging").

140. V7. AVd rechlspratk RuS 14 december $1981, \mathrm{tB} / \mathrm{S}, \mathrm{V}$, nr. 246. Voor een combinatic van 'feitelijke handeling' en 'besluit van algemene strekking' zie Vz. Afd. rechispraak RuSs november $1979,1 B / 5, \mathrm{~V}$, ne. 147.

141. KB 18 decembell 1973, AB $1975,6$.

142. Zie art 2. lid 1 . Wot BAB (wervallen).

143. Vgl, Rappont ABAR, nr. 3.2.1, onder b.

144. Zie noot 1 . 
145. Afd. rechtspraak RYS 1 december 1977. AB $197 \%$, 208. Zie poorts ook nog $\mathrm{kz}$, Ald. rechtspraxk RvS 16 augustus 1977, tB/S, V. blz. 116, alsmede Steenbeek, Wet administratheve rechtsprak owerheidsbeschkkingen, a.w. ble.75-76, die natan ankiding van deze juris-

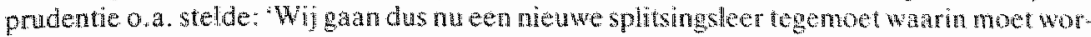
den aangehaakt atan de nate wasin het bes/uit al of nief een publickrechtelik karakter draagt' (b/z, 76).

146. Vgl. de preadwezen vor de Vereniging voor Administratief Recht wn 1982 over De omwang van de rechtsbescherning; door P.J.J. wan Buren en M. de Groot-Sjenizer. Geschrif VAR LXXXVMI, H. D. Tjeenk Willink, Alphenasn den Rijn 1982; alsmede her Verslag van de algemene vergadering (Geschrift WAR LXXXIX). 